\title{
CODES OF CORPORATE GOVERNANCE OF LATIN AMERICAN COUNTRIES: ANALYSIS OF UN PRACTICES
}

\author{
AGNALDO A. SANTOS \\ (iD) https://orcid.org/0000-0003-3205-9237 \\ SERGIO F. CRISPIM ${ }^{1}$ \\ (iD) https://orcid.org/0000-0002-4060-8315 \\ EDUARDO C. OLIVA ${ }^{1}$ \\ (iD) https://orcid.org/0000-0002-7454-3759 \\ MARCOS DORNELLES ${ }^{1}$ \\ (iD) https://orcid.org/0000-0003-4872-1336
}

To cite this paper: Santos, A. A., Crispim, S. F., Oliva, E. C., \& Dornelles, M. (2020). Codes of corporate governance of Latin American countries: Analysis of UN practices. Revista de Administração Mackenzie, 21 (6), 1-28. doi:10.1590/1678-6971/eRAMD200061

Submission: Mar. 29, 2020. Acceptance: Aug. 18, 2020.

Municipal University of São Caetano do Sul (USCS), São Caetano do Sul, SP, Brazil.

\footnotetext{
(cc) $\mathbf{B Y}$

This paper may be copied, distributed, displayed, transmitted or adapted for any purpose, even commercially, if provided, in a clear and explicit way, the name of the journal, the edition, the year and the pages on which the paper was originally published, but not suggesting that RAM endorses paper reuse. This licensing term should be made explicit in cases of reuse or distribution to third parties.

Este artigo pode ser copiado, distribuído, exibido, transmitido ou adaptado para qualquer fim, mesmo que comercial, desde que citados, de forma clara e explícita, o nome da revista, a edição, o ano e as páginas nas quais o artigo foi publicado originalmente, mas sem sugerir que a RAM endosse a reutilização do artigo. Esse termo de licenciamento deve ser explicitado para os casos de reutilização ou distribuição para terceiros.
} 


\section{ABSTRACT}

Purpose: For the stability of the organizational environment, corporate governance has become an indispensable condition. By adopting corporate governance codes, companies seek to compete differently in the market, valuing transparency as a guiding principle of relationships established in the various business segments. This article aims to compare the characteristics of corporate governance codes adopted by Latin American countries, including Brazil, Mexico, Argentina, Colombia, Chile, and Peru, through the set of practices recommended by the UN. Originality/value: The article studies the adoption of corporate governance codes adopted by Latin American countries, including Brazil, Mexico, Argentina, Colombia, Chile, and Peru.

Design/methodology/approach: This is a qualitative and quantitative descriptive study. The data were analyzed in-depth using content analysis techniques and complemented by hierarchical cluster analysis, with the Ward method, using the Jaccard and the Russell and Rao methods.

Findings: It was found that the corporate governance codes issued by Brazil, Colombia and Argentina converge with the UN guide. While the corporate governance code issued by Peru partially converges. The observed convergence suggests a concern with the demands of international investors. Finally, it was found that the corporate governance codes issued by Chile and Mexico have low convergence with the UN guide. This represents the lowest level of convergence between the countries investigated, indicating a greater concern with the local context than with international standards.

\section{KEYWORDS}

Corporate governance. Governance codes. UN. Cluster analysis. Latin American countries. 


\section{INTRODUCTION}

Several scandals that occurred in the early 2000s led the United States to enact the Sarbanes-Oxley (Sarbanes-Oxley ACT, 2002) Act in order to reduce the possibility of administrators and auditors to defraud company results, as in the Enron, WorldCom and Tyco cases, among other companies (Bequai, 2003) involved. In order to avoid or reduce them, in addition to the specific legislations, corporate governance was developed, addressed for the first time by Monks (1991) and, subsequently, by the partnership between Monks and Minov (1995). However, since the work of Berle and Means (1984), there have been many studies on the capital structure, which is one of the essential factors in the different governance models.

Corporate governance enables the creation of mechanisms that enable the control and monitoring of businesses (Mendes de Luca, Martins, Ribeiro Maia, \& Coelho, 2010). Since then, member States of the United Nations (UN) have taken several actions to strengthen their regulatory frameworks in this area to restore investor's confidence and improve the transparency and the responsibility of the organizations (United Nations Conference on Trade and Development [Unctad], 2006). An important initiative was the publication by the UN, in 2006, of a Guide to Good Corporate Governance Practices in order to promote better awareness in countries and companies that are not sufficiently adherent to international good practices and, consequently, fail to satisfy the investors' expectations regarding companies (Unctad, 2006).

With the advent of online databases of academic articles (Ebsco Host, Web of Science, Scopus, Spell, Google Scholar, Capes Journals), facilitated by the internet, it is possible to find articles on Corporate Governance Codes. In the Web of Science Database (2020) of the Institute for Scientific Information (ISI) alone, for example, in a research with the logic TS = "corporate governance" AND TS = "code", in May 2020, 765 titles were found. From 2011 to 2020 (last analysis in May/2020), out of that, 579 titles were found (75\% of published titles), the largest number of publications was in 2017 (98 titles).

Given the above, this article aims to compare the characteristics of the governance codes adopted by the Latin American countries Brazil, Mexico, Argentina, Colombia, Chile and Peru based on the set of practices recommended by the UN. The article intends to differ from the publication by Oliveira, Almeida, Stefe and Cunha (2014), which compared the Corporate 
Governance Code adopted by the countries that make up the Brics group (Brazil, Russia, India, China and South Africa), and Kitagawa \& Ribeiro (2009), which tries to identify corporate governance practices of companies in Brazil, Argentina, Chile and Mexico in accordance with the principles recommended by the Organisation for Economic Co-operation and Development (OECD). Specifically on publications from South America, the Web of Science database (2020) presents 18 publications, among which are the publications by Barco and Briozzo (2020), Correia and Lucena (2020), Méndez Beltrán, Lugo Romero and Valenzuela Melo (2018) and Macías and Román (2014).

In Latin America, the six countries represent approximately $92 \%$ of the region's Gross Domestic Product (GDP), with emphasis on Brazil (1.885 trillion dollars), Mexico (1.22 trillion dollars) and Argentina (519 billion dollars). Brazil (12), Mexico (8), Chile (5), Colombia (2), Argentina (2) and Peru (1) add up to 30 publicly traded companies. Brazil (29) in 2018 had an average financial volume of US $\$ 1.36$ billion of the American Depositary Receipts (ADR), standing out over the other countries in Latin America (Word Bank, 2019).

This article is justified by the growing importance, visibility and interest that corporate governance arouses in companies, investors and researchers, and by the fact that the prospect of a regional profile at the level of Latin America has still been little explored.

Thus, this article addresses in the second section a review of the literature covering corporate governance and the categories of disclosure of corporate governance recommended by the UN. In the third section, it presents the characterization and the research methods used. The fourth section presents the practices recommended by the UN and a comparative analysis among the governance codes in developing countries. Finally, in the fifth section, the final considerations followed by the research references are presented.

\section{THEORETICAL FOUNDATIONS}

\subsection{Corporate governance: codes of good practice}

Corporate governance, as well as the ownership structure of companies and the legislation of stock exchanges, among other political and social characteristics, may differ from country to country (Qurashi, 2017) due to the different stages of economic development of each one (Oliveira Neto, Medeiros, \& Queiroz, 2012; Qurashi, 2017). 
Roe (2005) identifies three types of corporate governance: 1. external corporate governance - or rules - that guide how companies can be run; 2. horizontal corporate governance, which govern the limits of the majority shareholder; and 3. vertical corporate governance, which limits the actions of the low-level management according to the shareholders.

The corporate governance Codes are useful for the formalization of a series of recommendations, and are intended to correct possible deficiencies in the governance structure of companies (Essen, Engelen, \& Carney, 2013; Schiehll \& Martins, 2016) in an aligned manner with the purpose of the Corporate Governance to guarantee to the investors and to the company the returns on investments made (Qurashi, 2017).

The first corporate governance codes were published in the early 1990s, and today they exist in more than 100 countries, each according to the economic condition and adaptation of other codes already published, improving their versions and updates (European Corporate Governance Institute, 2019). The first code of good corporate governance practices published was the Report of the Committee on the Financial Aspects of Corporate Governance, by the United Kingdom (Cadbury, 1992). Then, the codes The Toronto report on corporate governance (Toronto Stock Exchange, 1994), from Canada, and the Principles of corporate governance: Analysis and recommendations, from the United States (The American Law Institute, 1994) were edited.

The spread of codes of good governance practices in several countries gained strength due to the pressure created by the OECD. Brazil had its first edition of the governance code in 1999. In the document, conditions were pointed out for good governance and its relationship with the capital market, growth of organizations and the positive effects on the economic growth of nations (Lodi, 2000). Rules for dealing with agency conflicts and contributions to the development of codes for member and non-OECD countries, regulatory authorities, capital markets, institutional investors, private equity funds, investor associations, and corporate rating agencies were also defined. (Lodi, 2000).

These three moments (Monks, Cadbury. and OECD) were decisive to highlight the break in the hegemony of the managers, the country commission that advocates for best practices and the need for multilateral institutions that contribute to the growth of the countries, and also to evidence the development of the countries. Issues such as creating value, creating wealth and maximizing return on investments and relationships with the managers who are members of the executive management, shareholders and boards of directors are recurring issues for organizations among the various governance models practiced, which differ by common characteristics and predominant 
models in the companies in each country. These moments became the basis for the assessment of governance practices in emerging countries, as well as for the development of codes by such countries (Aguilera \& CuervoCazurra, 2009).

Governance codes have evolved in their understanding as principles of economic crises (Mees \& Smith, 2019), national culture in the Corporate Governance Code (Humphries \& Whelan, 2017), inclusion of emerging themes such as gender diversity (Sultana, Cahan, \& Rahman, 2020), use of information technology (De Haes, Huygh, Joshi, \& Caluwe, 2019). Australia, for example, adopted a new edition after the crises in the years 2007-2008, under pressure from local investors (Mees \& Smith, 2019). It is important that the codes edited by each country are reviewed periodically, over an average period of four years (Zulkafli, Hooy, \& Ooi, 2017).

On the one hand, Corporate Governance Codes come into existence, edited by each country. On the other hand, companies have come to declare the practice, adherence and compliance or not to the principles: the company is not obliged to comply with the principles, although it should explain the reasons why it does not do it, adopting a concept that companies have different conditions, such as their size (Barco \& Briozzo, 2020; Reddy, 2019). Nigeria, which has a corporate governance code based on the AngloSaxon model and adopts the "comply or explain" approach, in some cases, adopts the "comply" approach, due to the performance of the regulatory authority (Ajibo \& Ajibo, 2018).

Originally, the Brazilian Governance Code was edited by the Brazilian Institute of Corporate Governance (IBGC), the Banco do Brasil Employees' Pension Fund, B3 (stock exchange) and the Securities and Exchange Commission (CVM), bringing contributions from diversified institutions: a representative of civil society, an institutional investor, an investor from the capital market and, finally, a regulatory body. A similar movement was made in Japan, in the United States and in the United Kingdom, aiming to contribute to the sustainable performance of the organizations and to influence the society agents towards a greater transparency, justice and accountability (OECD, 2016).

In this discussion, it is worth mentioning the role of the International Standards of Accounting and Reporting (Isar), a UN body that aims to help developing countries and economies in transition to implement better transparency and accounting practices in companies, with a view to facilitate flows of investment and economic development (Viana, Costa, Cabral \& Santos, 2017). Among the various initiatives promoted by Isar, we highlight the publication, in 2006, of the Guidance on good practices in corporate governance 
disclosure. This guide aimed to promote more corporate transparency, including better disclosure of standards related to corporate governance, thus helping developing countries and countries with economies in transition to increase their capacity to attract foreign investments, thus, improving the communication of their ventures with interested parts (Unctad, 2006).

In the case of some emerging markets, such as Brazil, the nature of corporate governance positively affects the company's performance; it is a way that in which in other countries can be considered an end (Black, De Carvalho, \& Gorga, 2012). In countries with companies where there is a dissemination of a strong and widely accepted corporate governance, there is a greater appreciation attributed to the capital, which may reflect in investment in these countries. Thus, the cost of obtaining capital would be higher, even with the perception that there is risk associated with the investment, but the governance mechanisms may be related to the good performance of the companies (Al-Hares, 2019).

The objectives of the corporate governance codes of Latin American countries are diversified: instruments to protect the investor, creditor and stakeholder rights, seeking to avoid or limit the possibility of disseminating asymmetric information (Argentine code); investor access to sufficient information to make correct investment decisions (Chilean code); corporate practices that raise corporate governance standards (Colombian code); corporate governance culture improving the perception of corporations by investors, promoting business development and contributing to the creation of value in the Peruvian economy (Peruvian code); and, finally, the process of institutionalization and transparency of operations, for greater competitiveness in a global world, and access to financing on favorable terms, in addition to stable succession and continuity (Mexican code). Most of the Latin American codes have common content, such as a section dedicated to transparency, performance of the board of directors and treatment of the shareholders and stakeholders (OECD, 2016).

The UN publication, in 2006, of the Guidance on disclosure of good corporate governance practices (Unctad, 2006), was made up of a set of 52 disclosure items referring to good corporate governance practices in five different parts: 1 . financial transparency; 2 . corporate responsibility and compliance; 3 . audit; 4 . shareholding structure and exercise of control rights; 5. structure and process of the board and management. And in 2008, the UN examined the governance practices set out in their guide for 100 companies in emerging markets, bringing together the top ten from each of the following countries: South Africa, Brazil, China, South Korea, India, Indonesia, Israel, Malaysia, Mexico and Russia (Unctad, 2009). In these 52 practices recom- 
mended by the UN, it is possible to identify, in a subjective way, in the interpretation and judgement of the required information, the procedures for directing and controlling companies and the processes used by the board of directors for the purpose of monitoring and supervising the management administration.

\subsection{Some practices recommended by the UN}

Among the corporate governance practices recommended by the UN, the following stand out: a) shareholder structure and exercise of control rights; b) structure and process of the board of directors and management, seeking to add a low bias of the possibility of data. A brief description of the two practices follows.

\subsubsection{Ownership structure and exercise of control rights}

The shareholding structure can be understood as an effective control tool, as it allows aligning the interests of managers and owners; and it can be established in two dimensions: 1 . the first dimension represents the concentration of ownership, which refers to the number of shares held by a shareholder or by a group of shareholders; 2 . the second one is the identity of the majority shareholder, that is, the category that holds the controlling interest of the company, such as family, government, bank, institutional investor or non-financial company (Campos, 2006; Correia, Amaral, \& Louvet, 2011). The main objective of the shareholding structure is to ensure the compliance of the company managers with the interests of the shareholder, and also the mitigation of misalignment of interests between the shareholder (main) and the managers (agents) (Brellochs, 2008).

The shareholding structure must be fully disclosed to all interested parties, and the changes must be disclosed to the market as soon as a company becomes aware. The shareholding structure of a company is of great importance in an investment decision, especially regarding to the equitable treatment of the shareholders. It is recommended that this disclosure includes the concentration of equity interests, for example, the interests of the 20 largest shareholders. This piece of information is of particular interest to minority shareholders (OECD, 2004).

Brellochs (2008) points up that corporate governance consists of a system by which stakes are directed and monitored; and it involves relationship, legitimacy and interaction with the parts involved in this system, as if the 
shareholders were inside the company and in direct contact with the executive board. It should be noted that the participation is determined according to the legislation of the country in which the organization is located, the characteristics of the company itself and the strategic objectives of the holding company (Brellochs, 2008; Kiel, Hendry, \& Nichol-Son, 2006).

The control structure and how the shareholders or other members of the organization can exercise their control rights through voting or other means must be disclosed. Any agreement under which some shareholders may have a degree of control disproportionate to their shareholding, whether through differential voting rights, appointment of directors or other mechanisms, must be disclosed. Any specific structures or procedures in place to protect the interests of minority shareholders must be disclosed. In certain cases, control is exercised indirectly through the ownership of one or several entities that, in turn, collectively control a company, that is, a pyramid structure. In such cases, the disclosure of the final control is considered a recommended practice (OECD, 2004).

A company may have a single shareholder or a group of shareholders with majority control of the company, either by holding the majority of the company's outstanding assets, or by holding shares with superior voting rights. In this situation, without safeguards for minority shareholders, the latter group may be adversely affected. This issue is emphasized by several codes, including by OECD principles (OECD, 2004).

As noted in the OECD principles, information on processes may need to be supplemented with information on the shareholding structure in order to identify possible conflicts of interest, transactions with related parts and inside information. When disclosing the shareholder structure, information must also be provided on shareholders' agreements, voting limits and holdings in other companies, as well as the rights of different classes of shares that the company may have issued (OECD, 2004).

\subsubsection{Board and management structure and process}

Corporate governance is directly related to the decision-making process in the top management. This involves the relationships among the main characters of business organizations, such as shareholders, directors and executives represented, respectively, by the following management bodies: general meeting, board of directors and executive board, including the composition of the committees, succession plans and the performance evaluation processes. 
The board of directors consists of the main component of the governance system, whose role is to be the link between the ownership and the management, deciding the direction of the business according to the best interest of the organization as a whole (Instituto Brasileiro de Governança Corporativa [IBGC], 2010). The benefits it can bring to organizations, according to IBGC (2010) are: 1 . protection and enhancement of the organization; 2 . optimization of long-term return on investment; 3 . balance among the interests of the parts (shareholders and other stakeholders). Discussions about the importance of the boards of directors as a corporate governance tool for informational asymmetry took shape in the late 1980s, as highlighted by Brugni, Bortolon, Almeida and Paris (2013).

It should be noted that, according to IBGC (2015), the duties of the directors must be exercised independently and cannot be confused with the role of the State as a controlling shareholder. According to the body, it is essential that the board of directors prevent and manage situations of conflict of interest and lead the functioning of the governance system with authority and diligence to fully carry out its activities. To that end, you must avoid the concentration of power and observe good corporate governance practices, so the presidency of the board of directors and the role of chief executive or chief executive officer must be exercised by different people. ElGammal et al. (2017) admit that the board is responsible for determining standards, ideals and principles, and ensure that it is established.

The board member must also be exempt from fundamental conflict of interest and must always be attentive to the organization's affairs. In addition, he must understand that his duties and responsibilities are comprehensive and not restricted to the board meetings (IBGC, 2015).

Bergamini (2005) reinforces that the need for segregation between the functions of governance and management becomes unquestionable, and the board of directors is responsible for the strategic orientation and supervision of the acts of the executive board, which, in turn, takes care of the company management. The executive board is responsible for the risk management. However, it is up to the board to supervise this management, establishing good governance practices that include the definition of procedures related to risk management.

\section{METHOD - ANALYSIS}

This research has a descriptive character, focused on a specific group of Latin American countries - Brazil, Mexico, Argentina, Colombia, Chile and 
Peru. The choice of these countries stems from the importance of the economies in the region and the adoption of the corporate governance principles and practices that are the object of the study. The focus will be the analysis of two practices recommended by the UN and highlighted in the literature review: 1. shareholding structure and exercise of the control rights; and 2. structure and process of the board of directors.

The research has a documentary character, as it is based on a review of the good corporate governance practices recommended in the codes of the six countries sampled, based on the recommendations of the UN guide:

\section{(Figure 3.1)}

\section{CODES OF CORPORATE GOVERNANCE OF LATIN AMERICAN COUNTRIES}

\begin{tabular}{lll}
\hline Country & Year & \multicolumn{1}{c}{ Code } \\
\hline Argentina & 2003 & $\begin{array}{l}\text { Código de mejores prácticas de gobierno de las organizaciones para la República } \\
\text { Argentina }\end{array}$ \\
\hline \multirow{2}{*}{ Brazil } & 2015 & Código das melhores práticas de governança corporativa - 5th edition \\
\cline { 2 - 3 } & 2018 & Código brasileiro de governança corporativa - companhias abertas \\
\hline \multirow{3}{*}{ Colombia } & 2004 & Framework code of good corporate for small and medium-size enterprises \\
\cline { 2 - 3 } & 2009 & Colombian code of best practice \\
\hline Chile & 2017 & Principios de gobierno corporativo \\
\cline { 2 - 3 } & 2017 & Código sistema de empresas SEP \\
\hline Mexico & 2018 & Código de principios y mejores prácticas de gobierno corporativo \\
\hline Peru & 2013 & Código de buen gobierno corporativo para las sociedades peruanas \\
\hline
\end{tabular}

Source: European Corporate Governance Institute (2019).

The collected data were submitted to a qualitative analysis of documentary content, using the Atlas.ti software. The names of the five categories and 52 subcategories of the UN guide (for example, shareholder structure, exercise of control rights, general meetings) were used as keywords in the analysis of the country codes. With this procedure, the level of convergence of each national corporate governance code to the UN guide was assessed. Following the example of Zattoni and Cuomo (2008), a dummy variable was created for each practice described in the UN guide. The variable was scored according to the inclusion in each national Corporate Governance code $(0=$ absent, 1 = present). 
The research emphasized the comparison of the practices contained in each national corporate governance code with the recommendations of the UN Guide, and analyzed the nature of the issuing institutions regarding the purpose of adopting the codes and their relation to the inspection of the capital market in view of the globalized environment, or the inspection of the corporate governance by local companies. The research does not compare the content of the codes of the different countries in detail, but the content corresponding to the recommendations of international institutions represented by the UN. It is important to remember that the codes were developed in a local context, based on their laws and on the regulations of their securities commissions, in addition to some advocacy institutions already established in some countries, such as the IBGC in Brazil.

The corporate governance codes of Brazil, Mexico, Argentina, Colombia, Chile and Peru deal with more recurring themes, such as shareholders, control environment, conflict of interest, board of directors, risk management, management, transparency and disclosure, and other more specific themes, according to Figure 3.2. The research will focus on the analysis of the two aspects described in the literature review.

\section{(Figure 3.2)}

CONTENTS OF THE CORPORATE GOVERNANCE CODES OF THE LATIN-AMERICAN COUNTRIES

\begin{tabular}{|c|c|c|c|c|c|c|}
\hline Content & ARG & BRA & $\mathrm{CHI}$ & COL & MEX & PER \\
\hline Shareholders & $\sqrt{ }$ & $\sqrt{ }$ & $\sqrt{ }$ & $\sqrt{ }$ & $\sqrt{ }$ & $\sqrt{ }$ \\
\hline Control environment & $\sqrt{ }$ & $\sqrt{ }$ & $\sqrt{ }$ & & $\sqrt{ }$ & $\sqrt{ }$ \\
\hline Conflict of interests & $\sqrt{ }$ & $\sqrt{ }$ & $\sqrt{ }$ & $\sqrt{ }$ & & $\sqrt{ }$ \\
\hline Board of directors & $\sqrt{ }$ & $\sqrt{ }$ & $\sqrt{ }$ & & $\sqrt{ }$ & $\sqrt{ }$ \\
\hline Risk management & & & $\sqrt{ }$ & & $\sqrt{ }$ & \\
\hline Management & $\sqrt{ }$ & $\sqrt{ }$ & $\sqrt{ }$ & $\sqrt{ }$ & & $\sqrt{ }$ \\
\hline Transparency and disclosure & $\sqrt{ }$ & $\sqrt{ }$ & $\sqrt{ }$ & $\sqrt{ }$ & $\sqrt{ }$ & $\sqrt{ }$ \\
\hline Others & ARG & BRA & $\mathrm{CHI}$ & COL & MEX & PER \\
\hline Social responsibility & $\sqrt{ }$ & & $\sqrt{ }$ & $\sqrt{ }$ & & \\
\hline Intellectual property protection & $\sqrt{ }$ & & & & & \\
\hline Anti-bribery policy & $\sqrt{ }$ & & & & & \\
\hline
\end{tabular}




\section{(Figure 3.2 (conclusion))}

\section{CONTENTS OF THE CORPORATE GOVERNANCE CODES OF THE LATIN-AMERICAN COUNTRIES}

\begin{tabular}{|c|c|c|c|c|c|c|}
\hline Others & ARG & BRA & $\mathrm{CHI}$ & COL & MEX & PER \\
\hline Electronic communication & $\sqrt{ }$ & & & & & \\
\hline Social investment policies & $\sqrt{ }$ & & & & & \\
\hline Dispute resolution & & & $\sqrt{ }$ & & & \\
\hline Payment & $\sqrt{ }$ & $\sqrt{ }$ & $\sqrt{ }$ & & $\sqrt{ }$ & $\sqrt{ }$ \\
\hline Family company & & & $\sqrt{ }$ & & & \\
\hline Information security & & & & $\sqrt{ }$ & & \\
\hline $\begin{array}{l}\text { Companies not registered in the public registry } \\
\text { of the stock market }\end{array}$ & & & & & & $\sqrt{ }$ \\
\hline Purchases and acquisitions & & & $\sqrt{ }$ & & & \\
\hline Crises management & & & $\sqrt{ }$ & & & \\
\hline
\end{tabular}

Figure 3.3 presents the data survey of the principles identified in the codes of each country, in the categories: 1 . shareholding structure and exercise of control rights (questions 1 to 9 ) and 2. structure and process of the board and management (questions 34 to 52), which summarize 28 items of the 52 corporate governance practices recommended by the UN.

\section{(Figure 3.3)}

\section{ENCODED QUOTES IN BINARY VALUES}

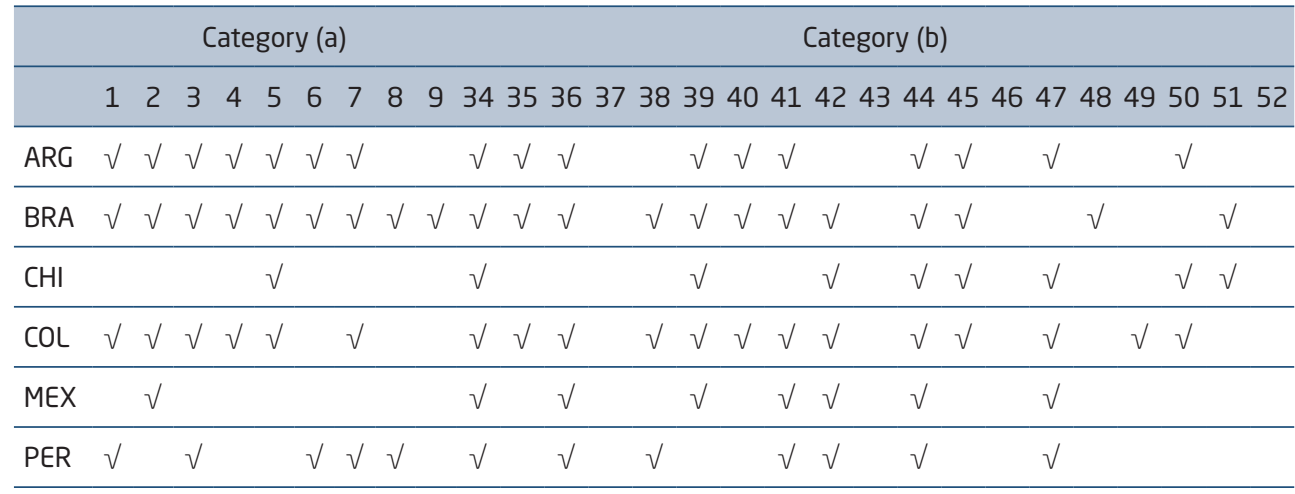


No citations were found for the codifications "composition and function of the structures of the government commission", "mechanisms for "checks and balances", "types and functions of external executive and management positions" and "remuneration policy for senior executives who leave the company as a result of a merger or acquisition".

\subsection{Ownership structure and the exercise of control rights}

Figure 3.1.1 presents the data survey of the principles identified in the codes of each country, in the category (a) shareholding structure and exercise of the control rights (questions 1 to 9).

\section{(Figure 3.1.1)}

CATEGORY "OWNERSHIP STRUCTURE AND EXERCISE OF THE CONTROL RIGHTS" OF THE CORPORATE GOVERNANCE PRACTICES RECOMMENDED BY THE UN

\begin{tabular}{|c|c|c|c|c|c|c|}
\hline $\begin{array}{l}\text { Ownership structure and the exercise } \\
\text { of the control rights }\end{array}$ & ARG & BRA & $\mathrm{CHI}$ & COL & MEX & PER \\
\hline 1. Ownership structure & $\sqrt{ }$ & $\sqrt{ }$ & & $\sqrt{ }$ & & $\sqrt{ }$ \\
\hline 2. Process for holding the annual general meeting & $\sqrt{ }$ & $\sqrt{ }$ & & $\sqrt{ }$ & $\sqrt{ }$ & \\
\hline 3. Changes in equity interests & $\sqrt{ }$ & $\sqrt{ }$ & & $\sqrt{ }$ & & $\sqrt{ }$ \\
\hline 4. Availability and accessibility to the meeting agenda & $\sqrt{ }$ & $\sqrt{ }$ & & $\sqrt{ }$ & & \\
\hline 5. Control framework & $\sqrt{ }$ & $\sqrt{ }$ & $\sqrt{ }$ & $\sqrt{ }$ & & \\
\hline 6. Control rights & $\sqrt{ }$ & $\sqrt{ }$ & & & & $\sqrt{ }$ \\
\hline 7. Control and corresponding shareholding & $\sqrt{ }$ & $\sqrt{ }$ & & $\sqrt{ }$ & & $\sqrt{ }$ \\
\hline $\begin{array}{l}\text { 8. Rules and procedures governing the acquisition of } \\
\text { control in the capital markets }\end{array}$ & & $\sqrt{ }$ & & & & $\sqrt{ }$ \\
\hline 9. Anti-takeover measures & & $\sqrt{ }$ & & & & \\
\hline
\end{tabular}

Source: Elaborated by the authors.

From Figure 3.1.1, it is possible to identify the variables "process for holding the annual general meeting" and "control framework" as the most important categories of "ownership structure and the exercise of the control rights".

From the conclusion of the data collection and in addition to this research, the hierarchical cluster analysis technique with the Ward method 
was used, using the Jaccard distance calculation as a measure of similarity in observations for binary variables, in which 1 is presented for identical samples and 0 for different samples (Ferreira, Mota, Silva, Marangon, \& Santos, 2008). The $6 \times 6$ dimension proximity matrix was built.

(Figure 3.1.2)

SIMILARITY MATRIX USING JACCARD MEASURE

\begin{tabular}{lcccccc}
\multicolumn{1}{c}{ Case } & Argentina & Brazil & Chile & Colombia & Mexico & Peru \\
\hline Argentina & 1 & 0.093 & 0.833 & 0.000 & 0.833 & 0.417 \\
\hline Brazil & 0.093 & 1 & 0.870 & 0.222 & 0.870 & 0.352 \\
\hline Chile & 0.833 & 0.870 & 1 & 0.806 & 1.000 & 1.000 \\
\hline Colombia & 0.000 & 0.222 & 0.806 & 1 & 0.806 & 0.583 \\
\hline Mexico & 0.833 & 0.870 & 1.000 & 0.806 & 1 & 1.000 \\
\hline Peru & 0.417 & 0.352 & 1.000 & 0.563 & 1.000 & 1 \\
\hline
\end{tabular}

Source: Elaborated by the authors

(Figure 3.1.3)

WARD LINK

\begin{tabular}{cccccccc}
\hline \multirow{2}{*}{ Stage } & \multicolumn{2}{c}{ Combined cluster } & & \multicolumn{2}{c}{ First cluster stage } & Next \\
\cline { 2 - 3 } & Cluster 1 & Cluster 2 & & & Cluster 1 & Cluster 2 & stage \\
\hline 1 & 1 & 4 & 0.000 & 0 & 0 & 2 \\
\hline 2 & 1 & 2 & 0.105 & 1 & 0 & 3 \\
\hline 3 & 1 & 6 & 0.411 & 2 & 0 & 5 \\
\hline 4 & 3 & 5 & 0.911 & 0 & 0 & 5 \\
\hline 5 & 1 & 3 & 1.611 & 3 & 4 & 0 \\
\hline
\end{tabular}

Source: Elaborated by the authors.

The Russell and Rao measure is also widely used and privileges only the similarities of the responses 1-1, different from the Jaccard measure, that does not take into account the frequency of the $0-0$ response pair considered irrelevant. 


\section{(Figure 3.1.4)}

SIMILARITY MATRIX USING RUSSELL AND RAO MEASURE

\begin{tabular}{lcccccc}
\multicolumn{1}{c}{ Case } & Argentina & Brazil & Chile & Colombia & Mexico & Peru \\
\hline Argentina & 0.778 & 0.000 & 0.857 & 0.143 & 0.857 & 0.429 \\
\hline Brazil & 0.000 & 1.000 & 0.857 & 0.143 & 0.857 & 0.286 \\
\hline Chile & 0.857 & 0.857 & 0.111 & 0.857 & 1.000 & 1.000 \\
\hline Colombia & 0.143 & 0.143 & 0.857 & 0.667 & 0.857 & 0.571 \\
\hline Mexico & 0.857 & 0.857 & 1.000 & 0.857 & 0.111 & 1.000 \\
\hline Peru & 0.429 & 0.286 & 1.000 & 0.571 & 1.000 & 0.556 \\
\hline
\end{tabular}

Source: Elaborated by the authors.

\begin{tabular}{|c|c|c|c|c|c|c|}
\hline \multirow{2}{*}{ Stage } & \multicolumn{2}{|c|}{ Combined cluster } & \multirow{2}{*}{ Coefficients } & \multicolumn{2}{|c|}{ First cluster stage } & \multirow{2}{*}{$\begin{array}{l}\text { Next } \\
\text { stage }\end{array}$} \\
\hline & Cluster 1 & Cluster 2 & & Cluster 1 & Cluster 2 & \\
\hline 1 & 1 & 2 & 0.000 & 0 & 0 & 2 \\
\hline 2 & 1 & 4 & 0.095 & 1 & 0 & 3 \\
\hline 3 & 1 & 6 & 0.393 & 2 & 0 & 5 \\
\hline 4 & 3 & 5 & 0.893 & 0 & 0 & 5 \\
\hline 5 & 1 & 3 & 1.619 & 3 & 4 & 0 \\
\hline
\end{tabular}

Source: Elaborated by the authors.

The answer information was obtained using the IBM SPSS Statistics v. 18.0. It is not a free software and its use is released for 14 days (trial version), giving enough time for application and analysis. Thus, countries were classified into homogeneous groups, similarities or dissimilarities among the groups (Maroco, 2003). From this point onwards, there was the formation of groups from the countries surveyed in each cluster, resulting in the following groupings:

- cluster 1 was composed of Argentina, Brazil, Colombia and Peru;

- cluster 2 was composed of Chile;

- cluster 3 was composed of Mexico. 
The principles "ownership structure", "changes in the ownership interests", "control rights", "control and corresponding shareholding" and "rules and procedures that govern the acquisition of control in the capital markets" were the items that formed cluster 1. Only "process for holding the annual general meeting" and "control structure" were the items that formed cluster 3 . Cluster 2 was formed by countries that met all the principles of the category "ownership structure and the exercise of the control rights".

Brazil complies with all the UN principles, including being the only one to present anti-takeover measures. It was not possible to identify the same with the principles of Chile, which has a principle aimed at companies with state control.

\subsection{Structure and process of the board and management}

Figure 3.2.1 presents the data collection of the principles identified in the codes of each country, in the category "structure and process of the board and administration" (questions 34 to 52 ).

(Figure 3.2.1)

CATEGORY "STRUCTURE AND PROCESS OF THE BOARD AND MANAGEMENT" OF CORPORATE GOVERNANCE PRACTICES RECOMMENDED BY THE UN

Structure and process of the board and management ARG BRA CHI COL MEX PER

34. Governance structures, such as commissions and other mechanisms to prevent conflicts of interest

35. Composition of the board of directors (executive and non-executive)

36. Role and functions of the board of directors

$\begin{array}{llllll} & \sqrt{ } & \sqrt{ } & \sqrt{ } & \sqrt{ } & \sqrt{ }\end{array}$

37. Composition and function of the government commission structures

38. Qualifications and biographical information about the board members

39. Determination and composition of the management payment

$\begin{array}{lllll}V & V & V & V & V\end{array}$

40. Material interests of the board and management members 
(Figure 3.2.1 (conclusion))

\section{CATEGORY "STRUCTURE AND PROCESS OF THE BOARD AND MANAGEMENT" OF CORPORATE GOVERNANCE PRACTICES RECOMMENDED BY THE UN}

\begin{tabular}{|c|c|c|c|c|c|c|}
\hline Structure and process of the board and management & ARG & BRA & $\mathrm{CHI}$ & COL & MEX & PER \\
\hline 41. Independence of the board of directors & $\sqrt{ }$ & $\sqrt{ }$ & & $\sqrt{ }$ & $\sqrt{ }$ & $\sqrt{ }$ \\
\hline $\begin{array}{l}\text { 42. Existence of procedure(s) for dealing with conflicts of } \\
\text { interest among the directors }\end{array}$ & & $\sqrt{ }$ & $\sqrt{ }$ & $\sqrt{ }$ & $\sqrt{ }$ & $\sqrt{ }$ \\
\hline
\end{tabular}

43. "Checks and balances" mechanisms

\begin{tabular}{llllllll}
\hline 44. Objectives, system and activities of risk management & $\sqrt{ }$ & $\sqrt{ }$ & $\sqrt{ }$ & $\sqrt{ }$ & $\sqrt{ }$ & $\sqrt{ }$ \\
\hline 45. Duration of the director's contracts & $\sqrt{ }$ & $\sqrt{ }$ & $\sqrt{ }$ & $\sqrt{ }$ & &
\end{tabular}

46. Types and functions of external executive and management positions

47. Existence of a succession plan

$\begin{array}{llllll} & V & V & \vee & \vee & V\end{array}$

48. Professional training and development activities

49. Number of external board and management positions held by directors

50. Performance evaluation process

$\checkmark \quad \sqrt{ } \quad \sqrt{ }$

51. Availability and use of the advisory mechanism during the reporting period

52. Compensation policy for senior executives who leave the company as a result of a merger or acquisition

Source: Elaborated by the authors.

In Figure 3.2.1, it is possible to identify the variables "number of external board and management positions held by directors", "duration of the director's contracts" and "professional training and development activities" as the most important in the "structure and process of the board and management" category in the UN practices.

From the conclusion of the data collection and in addition to this research, the hierarchical cluster analysis technique with the Ward method was used, using the Jaccard distance calculation as a measure of similarity in observations for binary variables, in which 1 is presented for identical samples and 0 for different samples. The $6 \times 6$ dimension proximity matrix was built. 


\section{(Figure 3.2.2)}

SIMILARITY MATRIX USING JACCARD MEASURE

\begin{tabular}{lcccccc}
\hline \multicolumn{1}{r}{ Case } & Argentina & Brazil & Chile & Colombia & Mexico & Peru \\
\hline Argentina & 1 & 0.488 & 0.664 & 0.000 & 0.552 & 0.869 \\
\hline Brazil & 0.488 & 1 & 0.840 & 0.253 & 0.759 & 0.759 \\
\hline Chile & 0.664 & 0.840 & 1 & 0.664 & 0.664 & 1.000 \\
\hline Colombia & 0.000 & 0.253 & 0.664 & 1 & 0.569 & 0.569 \\
\hline Mexico & 0.552 & 0.759 & 0.664 & 0.569 & 1 & 0.047 \\
\hline Peru & 0.869 & 0.759 & 1.000 & 0.569 & 0.047 & 1 \\
\hline
\end{tabular}

Source: Elaborated by the authors.

(Figure 3.2.3)

WARD LINK

\begin{tabular}{|c|c|c|c|c|c|c|}
\hline \multirow{2}{*}{ Stage } & \multicolumn{2}{|c|}{ Combined cluster } & \multirow{2}{*}{ Coefficients } & \multicolumn{2}{|c|}{ First cluster stage } & \multirow{2}{*}{$\begin{array}{l}\text { Next } \\
\text { stage }\end{array}$} \\
\hline & Cluster 1 & Cluster 2 & & Cluster 1 & Cluster 2 & \\
\hline 1 & 1 & 4 & 0.000 & 0 & 0 & 3 \\
\hline 2 & 5 & 6 & 0.24 & 0 & 0 & 5 \\
\hline 3 & 1 & 2 & 0.271 & 1 & 0 & 4 \\
\hline 4 & 1 & 3 & 0.751 & 3 & 0 & 5 \\
\hline 5 & 1 & 5 & 1.449 & 4 & 2 & 0 \\
\hline
\end{tabular}

Source: Elaborated by the authors.

In Figure 3.2.4, the similarity matrix is presented using the Russell and Rao measure, which differs from the Jaccard measure.

\section{(Figure 3.2.4)}

SIMILARITY MATRIX USING RUSSELL AND RAO MEASURE

\begin{tabular}{lcccccc}
\multicolumn{1}{c}{ Case } & Argentina & Brazil & Chile & Colombia & Mexico & Peru \\
\hline Argentina & 0.526 & 0.333 & 0.667 & 0.000 & 0.667 & 0.833 \\
\hline Brazil & 0.333 & 0.632 & 0.667 & 0.000 & 0.667 & 0.667 \\
\hline Chile & 0.667 & 0.667 & 0.421 & 0.500 & 0.833 & 1.000 \\
\hline
\end{tabular}




\section{(figure 3.2.4 (conclusion))}

SIMILARITY MATRIX USING RUSSELL AND RAO MEASURE

\begin{tabular}{lcccccc}
\multicolumn{1}{c}{ Case } & Argentina & Brazil & Chile & Colombia & Mexico & Peru \\
\hline Colombia & 0.000 & 0.000 & 0.500 & 0.684 & 0.500 & 0.500 \\
\hline Mexico & 0.667 & 0.667 & 0.833 & 0.500 & 0.368 & 0.667 \\
\hline Peru & 0.833 & 0.667 & 1.000 & 0.500 & 0.667 & 0.368 \\
\hline
\end{tabular}

Source: Elaborated by the authors

(Figure 3.2.5)

WARD LINK

\begin{tabular}{cccccccc}
\hline \multirow{2}{*}{ Stage } & \multicolumn{2}{c}{ Combined cluster } & & \multicolumn{2}{c}{ First cluster stage } & \multirow{2}{*}{$\begin{array}{c}\text { Next } \\
\text { stage }\end{array}$} \\
\cline { 2 - 3 } & Cluster 1 & Cluster 2 & & Cluster 1 & Cluster 2 & \\
\hline 1 & 2 & 4 & 0.000 & 0 & 0 & 2 \\
\hline 2 & 1 & 2 & 0.111 & 0 & 1 & 4 \\
\hline 3 & 5 & 6 & 0.444 & 0 & 0 & 5 \\
\hline 4 & 1 & 3 & 0.875 & 2 & 0 & 5 \\
\hline 5 & 1 & 5 & 1.417 & 4 & 3 & 0 \\
\hline
\end{tabular}

Source: Elaborated by the authors.

The formation of the groups of countries surveyed in each cluster was observed, resulting in the following composition:

- cluster 1 was composed of Argentina, Brazil and Colombia;

- cluster 2 was composed of Chile;

- cluster 3 was composed of Mexico and Peru.

It is possible to affirm that Argentina, Brazil and Colombia have principles more in line with those of the UN.

\section{DISCUSSION - FINAL CONSIDERATIONS}

The objective of the UN corporate governance Practices is to offer to the international investors greater transparency of information, protection for the shareholders, risk management, conflict of interest, management control, 
performance and succession of the board of directors. The codes developed by the countries are modified to adapt to the laws and regulations, including emphasizing specific principles of corporate governance. Of the countries analyzed, it is possible that the editions of the codes may favor some important elements, which do not yet exist: social responsibility; intellectual property protection; anti-bribery policy; electronic communication; social investment policies; dispute resolution; remuneration; family society; information security; companies not registered in the public registry of the stock market; purchases and acquisitions; crises management.

It is possible to identify that the content of the codes has principles for different types of companies, such as state-owned and family-owned companies in the Chilean code, and principles not yet addressed in the UN practices, such as specific principles of data protection and information technology.

It was found that the corporate governance codes issued by Brazil, Colombia and Argentina converge with the UN guide. While the corporate governance code issued by Peru converges partially. The observed convergence suggests a concern with the demands of the international investors. Finally, it was found that the corporate governance codes issued by Chile and Mexico have low convergence with the UN guide. This represents the lowest level of convergence among the researched countries.

In short, among the six researched countries in Latin America, the corporate governance codes of Brazil, Colombia and Argentina are the most closely aligned with the recommendations established in the UN document Guidance on good practices in disclosing corporate governance. In these countries, the development of corporate governance is clearly focused on the demands of the international investors, especially in the category "board and management structure and process". Comparatively, the convergence of the codes of Brazil and Colombia was superior to the codes of the other countries. On the other hand, the implementation of corporate governance is a developing initiative, even in countries that were pioneers in the concept. Thus, regardless of the current deficiencies, the issuance and dissemination of corporate governance codes in emerging economies is, in itself, an important step towards greater transparency and corporate citizenship.

Complementing the study through data collection, hierarchical evaluation clustering techniques were applied, rationalizing the ideal number of clusters and classifying the countries into homogeneous categories. From the results, it was possible to identify the countries that had the greatest similarities in the answers to the questionnaire in the same group, and this 
approach could contribute to the UN governance on good practices orientation, more directed in function of the homogeneities or particularities of the groups of countries.

\section{LIMITATIONS - FUTURE STUDIES}

The present study was able to meet its objective, analyzing each corporate governance code and, after analyzing all the codes, it was concluded that there are Latin American countries that have similarities in their principles and codes, some more aligned than others with the principles recommended by the UN, each country with some particularities, and that the codes have some similarities, but there is no uniformity. Despite the conclusions aligned with the objective proposed, the study has the limitation of being based on secondary sources, being desirable, in future studies, interviews with representatives of regulatory bodies and organizations. In addition, future researches could explore countries in other regions, or even an interregional and global comparison.

\section{CÓDIGOS DE GOVERNANÇA CORPORATIVA DOS PAÍSES LATINO-AMERICANOS: ANÁLISE DAS PRÁTICAS DA ONU}

\section{RESUMO}

Objetivo: Para a estabilidade do ambiente organizacional, a adoção de códigos de governança corporativa tornou-se uma importante condição para a estabilidade do ambiente organizacional por valorizar a transparência como princípio norteador das relações estabelecidas nos diversos segmentos de negócios e possibilitar a competição de forma diferenciada. Nesse sentido, este artigo tem o objetivo de comparar, com base em um conjunto de práticas recomendadas pela ONU, as características dos códigos de governança corporativa adotados na América Latina por Brasil, México, Argentina, Colômbia, Chile e Peru.

Originalidade/valor: $\mathrm{O}$ artigo estuda a adoção de códigos de governança corporativa adotados pelos países latino-americanos, pouco explorados sobre o tema de forma integrada.

Design/metodologia/abordagem: Trata-se de estudo descritivo qualitativo e quantitativo com análise em profundidade pelo uso de técnicas de 
análise de conteúdo, complementada pela análise hierárquica de clusters, por meio do método Ward, em que se utilizam medidas de similaridade de Jaccard e de Russell e Rao.

Resultados: Verificou-se que os códigos de governança corporativa emitidos pelo Brasil, pela Colômbia e pela Argentina convergem com o guia da ONU, enquanto o do Peru converge parcialmente. A convergência observada sugere uma preocupação com o alinhamento às demandas dos investidores internacionais. Por fim, constatou-se que os códigos de governança corporativa emitidos pelo Chile e México têm baixa convergência com o guia da ONU, sugerindo maior preocupação intrarregional do que com o alinhamento a padrões internacionais, o que pode levar a uma maior dificuldade na atração de investimento direto ou não.

\section{PALAVRAS-CHAVE}

Governança corporativa. Código de governança. ONU. Análise de conglomerados. Países latino-americanos.

\section{REFERENCES}

Aguilera, R. V., \& Cuervo-Cazurra, A. (2009). Codes of good governance. Corporate Governance: an International Review, 17(3), 376-387. doi:10.1111/ j.1467-8683.2009.00737.x

Ajibo, C., \& Ajibo, K. (2018). Mandatory versus discretionary rule dichotomy in the harmonization of corporate governance codes: Lessons for Nigeria. Journal of African Law, 63 (3), 385-411. doi:10.1017/S0021855319000287

Al-Hares, A. (2019). Corporate governance and cost of capital in OECD countries. International Journal of Ethics and Systems, 35(4), 665-690. doi:10. 1108/IJOES-02-2019-0043

Barco, E., \& Briozzo, A. (2020). Corporate governance code in Argentina: Analysis of the level of compliance. Retos - Revista de Ciencias de la Administracion Y Economia, 10(19), 45-63. doi:10.17163/ret.n19.2020.03

Bequai, A. (2003). Safeguards for IT managers and staff under the SarbanesOxley Act. Computers \& Security, 22(2), 124-127. doi:10.1016/S01674048(03)00208-6 
Bergamini, S., Junior (2005). Controles internos como um instrumento de governança corporativa. Revista do BNDES, 12(24), 149-188. Retrieved from https://web.bndes.gov.br/bib/jspui/bitstream/1408/13474/2/RB\% 2024\%20Controles\%20Internos\%20como\%20um\% 20Instrumento\%20 de\%20Governança\%20Corporativa_P_BD.pdf

Berle, A. A., \& Means, G. (1984). A moderna sociedade anônima e a propriedade privada. São Paulo: Abril Cultural.

Black, B. S., De Carvalho, A. G., \& Gorga, E. (2012). What matters and for which firms for corporate governance in emerging markets? Evidence from Brazil (and other BRIK countries). Journal of Corporate Finance, 18(4), 934-952. doi:10.1016/j.jcorpfin.2011.10.001

Brellochs, J. (2008). The corporate governance of subsidiaries in multinational corporations: Theoretical analysis and empirical evidence from Europe. Berlin: VDM Verlag.

Brugni, T. V., Bortolon, P. M., Almeida, J. E. de, \& Paris, P. K. (2013). Corporate governance: A panoramic view of Brazilian boards of directors. International Journal of Disclosure and Governance, 10(4), 406-421. doi:10. 1057/jdg.2013.22

Cadbury, A. (1992). Report of the Committee on the Financial Aspects of Corporate Governance. Gee: Committee on the Financial Aspects of Corporate Governance.

Campos, T. L. (2006). Estrutura da propriedade e desempenho econômico: Uma avaliação empírica para as empresas de capital aberto no Brasil. Revista de Administração da USP, 41 (4), 369-380.

Correia, L. F., Amaral, H. F., \& Louvet, P. (2011). Um índice de avaliação da qualidade da governança corporativa no Brasil. Revista Contabilidade $\mathcal{E}$ Finanças, 41 (4), 45-63. doi:10.1590/S1519-70772011000100004

Correia, T., \& Lucena, W. L. (2020). Board of directors and code of business ethics of Brazilian companies. RAUSP Management Journal, 55(2), 263-279. doi:10.1108/RAUSP-12-2018-0147

De Haes, S., Huygh, T., Joshi, A., \& Caluwe, L. (2019). National corporate governance codes and IT governance transparency in annual reports. Journal of Global Information Management, 27(4), 91-118. doi:10.4018/JGIM.2019 100105

Elgammal, A., Liu, B., Elhoseiny, M., \& Mazzone, M. (2017). CAN: Creative Adversarial Networks, Generating. "Art" by learning about styles and deviating from style norms. Retrieved from https://arxiv.org/pdf/1706. 07068.pdf 
Essen, M., Engelen, P., \& Carney, M. (2013). Does “Good” corporate governance help in a crisis? The impact of country and firm level governance mechanisms in the European financial crisis. Corporate Governance: an International Review, 21 (3), 201-224. doi:10.1111/corg.12010

European Corporate Governance Institute (2019). ECGI Global. Retrieved from https://ecgi.global/content/codes

Ferreira, R., Mota, A., Silva, J., Marangon, L., \& Santos, E. (2008). Comparação de duas metodologias multivariadas no estudo de similaridade entre fragmentos de floresta atlântica. Revista Árvore, 32(3), 511-521. doi:10.15 90/S0100-67622008000300012

Humphries, S., \& Whelan, C. (2017). National culture and corporate governance codes. Corporate Governance - The International Journal of Business in Society, 17(1), 152-163. doi:10.1108/CG-06-2016-0127

Instituto Brasileiro de Governança Corporativa (2010). Caderno de boas práticas para reuniões do conselho de administração. São Paulo: IBGC. Retrieved from https://edisciplinas.usp.br/pluginfile.php/2758341/mod_resource/ content/1/9.pdf

Instituto Brasileiro de Governança Corporativa (2015). Código das melhores práticas de governança corporativa. São Paulo: IBGC. Retrieved from https:// edisciplinas.usp.br/pluginfile.php/4382648/mod_resource/content/1/ Livro_Codigo_Melhores_Praticas_GC.pdf

Kiel, C. G., Hendry, K., \& Nichol-Son, G. J. (2006). Corporate governance options for the local subsidiaries of multinational enterprises. Corporate Governance, 14(6), 568-576. doi:10.1111/j.14678683.2006.00531.x

Kitagawa, C., \& Ribeiro, M. (2009). Governança corporativa na América Latina: A relevância dos princípios da OCDE na integridade dos conselhos e autonomia dos conselheiros. Revista Contabilidade E Finanças, 20(51), 61-76. doi:10.1590/S1519-70772009000300005

Lodi, J. B. (2000). Governança corporativa: O governo da empresa e o conselho (Vol. 2). Rio de Janeiro: Campus.

Macías, A., \& Román, F. (2014). Consecuencias económicas de la Reforma de Gobierno Corporativo en un mercado de capitales emergente. Pruebas de México. El Trimestre Económico, 81 (322), 357-412.

Maroco, J. (2003). Análise estatística: Com a utilização do SPSS. Lisboa: Silabo.

Mees, B., \& Smith, S. (2019). Corporate governance reform in Australia: A new institutional approach. British Journal of Management, 30, 75-89. doi:10.1111/1467-8551.12298 
Mendes de Luca, M. M., Martins, L. C., Ribeiro Maia, A. B., \& Coelho, A. C. (2010). Os mecanismos de auditoria evidenciados pelas empresas listadas nos níveis diferenciados de governança corporativa e no Novo Mercado da Bovespa. Contabilidade Vista \& Revista, 21 (1), 101-130. Retrieved from https://revistas.face.ufmg.br/index.php/contabilidadevistaerevista/article/ view/817

Méndez Beltrán, J., Lugo Romero, A., \& Valenzuela Melo, I. (2018). Production of positive financial returns given the distribution of good governance codes in listed organizations in Colombia. Revista Universidad y Empresa, 20(35), 169-196. doi:10.12804/revistas.urosario.edu.co/empresa/a.5846

Monks, R. (1991). Power and accountability. New York: Harper Business.

Monks, R., \& Minow, N. (1995). Corporate governance. Blackwell.

Oliveira, J. C., Neto, Medeiros, O. B., \& Queiroz, T. B. (2012). Governança corporativa e velocidade de incorporação de informações: Lead-lag entre o IGC e o IBrX. Revista Brasileira de Finanças, 10(1), 149-172. doi:10.12660/ rbfin.v10n1.2012.3048

Oliveira, M., Almeida, S., Stefe, R., \& Cunha, G. (2014). Comparative analysis of the corporate governance codes of the five Brics countries. Contabilidade, Gestão e Governança, 17(3), 49-70.

Organisation for Economic Co-operation and Development (1999). OECD principles of corporate governance. Retrieved from https://ecgi.global/sites/ default/files/codes/documents/principles_en.pdf

Organisation for Economic Co-operation and Development (2004). OECD principles of corporate governance. Retrieved from http://www.oecd.org/ corporate/ca/corporategovernanceprinciples/31557724.pdf

Organisation for Economic Co-operation and Development (2016). Strengthening corporate governance codes in Latin America.Retrieved from https://www.oecd.org/daf/ca/LART-2016-Strengthening-CorporateGovernance-Codes-Latin-America.pdf

Qurashi, M. (2017). Comparison of corporate governance codes for GCC countries with the UN best practices. BAM 2017 Conference Proceedings. Coventry, UK. Retrieved from https://www.researchgate.net/publication/ 319716462

Reddy, B. (2019). Thinking outside the box - Eliminating the perniciousness of box-ticking in the new corporate governance code. Modern Law Review, 82(4), 692-726. doi:10.1111/1468-2230.12415 
Roe, M. J. (2005). The institutions of corporate governance. In C. Ménard \& M. M. Shirley (Eds.), Handbook of new institutional economics. Kluwer.

Sarbanes-Oxley Act. (2002). Retrieved from http://www.soxlaw.com/

Schiehll, E., \& Martins, H. C. (2016). Cross-national governance research: A systematic review and assessment. Corporate Governance: an International Review, 24(3), 181-199. doi:10.1111/corg.12158

Sultana, N., Cahan, S., \& Rahman, A. (2020). Do gender diversity recommendations in corporate governance codes matter? Evidence from audit committees. Auditing - A Journal of Practice \& Theory, 39(1), 173-197. doi:10.2308/ajpt-52560

The American Law Institute (1994). Principles of corporate governance: Analysis and recommendations. St. Paul: American Law Institute. Retrieved from https://heinonline.org/HOL/LandingPage?handle=hein.ali/alicgv0082\& $\operatorname{div}=1 \& \operatorname{src}=$ home

United Nations Conference on Trade and Development (2006). Guidance on good practices in corporate governance disclosure. New York, Geneva: Unctad. Retrieved from https://unctad.org/en/docs/iteteb20063_en.pdf?user $=46$

United Nations Conference on Trade and Development (2009). Review of the implementation status of corporate governance disclosures: An examination of reporting practices among large enterprises in 12 emerging markets. International Accounting and Reporting Issues:2009 Review, Geneva, 10. doi:10.18356/721f7c6c-en

Viana, D. B. C., Junior, Costa, F. C. da, Filho, Cabral, A. C. de A., \& Santos, S. M. dos (2017). Disclosure de boas práticas de governança segundo recomendações da ONU: Um estudo nas companhias listadas no segmento novo mercado sob a perspectiva de porte empresarial. Revista de Ciências da Administração, 19(49), 102-116. doi:10.5007/2175-8077.2017v19n49p102

Web of Science (2020). Retrieved from http://apps.webofknowledge.com

Word Bank (2019). Retrieved from https://data.worldbank.org/indicator/ NY.GDP.MKTP.CD? name_desc $=$ false

Zattoni, A., \& Cuomo, F. (2008). Why adopt codes of good governance? A comparison of institutional and efficiency perspectives. Corporate governance: an International Review, 16 (1), 1-15. doi:10.1111/j.14678683.2008.00661.x

Zulkafli, A., Hooy, C.-W., \& Ooi, C.-A. (2017). Investigating the effectiveness of corporate governance code revisions on the perspective of the revision interval. International Journal of Business and Society, 18(3), 503-514. 


\section{AUthOR NOTES}

Agnaldo A. Santos, master from the Postgraduate Program in Administration (PPGA), Higher School of Advertising and Marketing (ESPM); Sergio F. Crispim, Ph.D from the School of Arts, Sciences and Humanities, University of São Paulo (USP); Eduardo C. Oliva, Ph.D from the Faculty of Economics, Administration, Accounting and Actuaries (FEA), University of São Paulo (USP); Marcos Dornelles, Ph.D from the Postgraduate Program in Administration (PPGA), Municipal University of São Caetano do Sul (USCS).

Agnaldo A. Santos is now Ph.D student at the Postgraduate Program in Administration (PPGA) of the Municipal University of São Caetano do Sul (USCS); Sergio F. Crispim is now professor and researcher at the Postgraduate Program in Administration (PPGA) of the Municipal University of São Caetano do Sul (USCS); Eduardo C. Oliva is now professor, researcher, PPGA manager and stricto sensu director of the Postgraduate Program in Administration (PPGA) of the Municipal University of São Caetano do Sul (USCS); Marcos Dornelles is now professor and researcher at the Department of Engineering of the Municipal University of São Caetano do Sul (USCS).

Correspondence concerning this article should be addressed to Agnaldo A. Santos, Rua Conceição, 321, Térreo, Conceição, São Caetano do Sul, São Paulo, São Paulo, Brazil, CEP 09530-060.

E-mail: agnaldoa@outlook.com.br

EDITORIAL BOARD

Editor-in-chief

Gilberto Perez

Associated Editor

Antonio Zoratto Sanvicente

Technical Support

Vitória Batista Santos Silva

\section{EDITORIAL PRODUCTION}

Publishing Coordination

Jéssica Dametta

Layout Designer

Emap

Editorial Intern

Paula Di Sessa Vavlis

Graphic Designer

Libro

Daniel de Almeida Leão 